\title{
Some Typical Problems of Entrepreneurship Education "Popularization" in Local Universities and Colleges
}

\author{
Houchun Ding, Li Jiang \\ Huanggang Normal College \\ Huanggang, Hubei, 438000
}

\begin{abstract}
This paper aims to examine the typical problems faced by the development of education "popularization" in local colleges and universities in China. Based on the actual situation of the education work of the typical university, this article adopts "typical case analysis" method and regard the real work experience as the active promoter of education, have a perspective on the typical crux of the education "popularization" development of local universities and colleges. The research shows that the teaching links are very weak and the marginalization is obvious. The direct participation of full-time teachers in entrepreneurship education is not sufficient and the construction strength is thin. "Competition Lead" effect is limited, emphasis on hardware and belittle software, the operation of the institutional platform has not formed a net force. These typical problems need to be resolved in the development of education "popularization" in local universities in China.
\end{abstract}

Keywords-Local colleges and universities; Entrepreneurship education; Educational popularization

\section{INTRODUCTION}

"Deepening the reform of institutions of higher learning innovation education" and "public entrepreneurship, peoples innovation" strategy is put forward, which makes the entrepreneurship education in colleges and universities began to pursue the" quality ", and demand "for all students". Under double pressures of "connotation" and "popularization", local universities should face their own truth first, find its ills, so is it possible in the "quantity and quality" to promote the development of "the gen education ". This paper takes our school as an example, based on the work of promoting entrepreneurship education in the university, tries to analyze and evaluate the typical crux of education "connotation" and "popularization " development of local universities and colleges.

\section{THE TEACHING LINK IS VERY WEAK, AND THE MARGINALIZATION IS OBVIOUS}

There is no doubt that the teaching link is education -including entrepreneurship education's core link. In this regard, our judgment is that the teaching link of entrepreneurship education is very weak and marginalized in local universities and colleges. In the actual view of our school, the specific performance is:

\section{A. Teaching is carried out relatively late, and with little accumulation}

The complete innovation and entrepreneurship of foreign systems started in the US in the 1940s[1], and it can date back to 1947 , when MylesMace opened a new curriculum "New enterprise management" for MBA students from Harvard business school [2]. Of course, China began to launch a pilot university to launch the entrepreneurship education in 2002, which is more comparable to the reference time point. However, from the perspective of the talent training program in our school (table 1), there is no curriculum setting for "entrepreneurship education" in our school "2005 talent training program". "Entrepreneurship and employment guidance" is set up in the 2007 edition of the talent training program. However, the appeal of its "employment guidance" makes the curriculum arrange for the senior year. As a result, the actual first time to start an entrepreneurship education curriculum has been around 2009. The immediate consequence of opening late is that we accumulate less. Aside from the fact that there is no fully implemented "talent training program for 2016", there is now only business school opening the entrepreneurship education "professional course", with one course and 32 class hours. While famous global entrepreneurship education universities often offer a rich set of education courses, such as the MIT entrepreneurship center, there are 35 courses related to entrepreneurship education [3].

TABLE I. CIRCUMSTANCE ENTREPRENEURSHIP EDUCATION CURRICULUM IN OUR UNIVERSITY'S TALENT TRAINING PROGRAM

\begin{tabular}{|c|c|c|c|c|c|c|}
\hline $\begin{array}{c}\text { Talent } \\
\text { training } \\
\text { program }\end{array}$ & $\begin{array}{c}\text { Whether } \\
\text { there are } \\
\text { related } \\
\text { courses }\end{array}$ & Course category & Course name & $\begin{array}{c}\text { Curriculum } \\
\text { teaching period }\end{array}$ & $\begin{array}{c}\text { Responsible } \\
\text { department }\end{array}$ & $\begin{array}{c}\text { Whether there are } \\
\text { no related } \\
\text { professional } \\
\text { courses }\end{array}$ \\
\hline
\end{tabular}




\begin{tabular}{|c|c|c|c|c|c|c|}
\hline \multicolumn{7}{|c|}{ Table I, cont. } \\
\hline $\begin{array}{l}\text { The } 2005 \\
\text { version }\end{array}$ & No & -- & -- & -- & -- & No \\
\hline $\begin{array}{l}\text { The } 2007 \\
\text { version }\end{array}$ & Yes & $\begin{array}{l}\text { Curriculum of } \\
\text { general } \\
\text { education }\end{array}$ & $\begin{array}{l}\text { Entrepreneurship and } \\
\text { employment guidance }\end{array}$ & 24 & $\begin{array}{l}\text { Recruitment and } \\
\text { employment office }\end{array}$ & $\begin{array}{l}\text { Entrepreneurship } \\
\text { theory and } \\
\text { practice (business } \\
\text { school;30 class } \\
\text { hours) } \\
\end{array}$ \\
\hline $\begin{array}{l}\text { The } 2013 \\
\text { version }\end{array}$ & Yes & $\begin{array}{l}\text { Curriculum of } \\
\text { general } \\
\text { education }\end{array}$ & $\begin{array}{l}\text { Entrepreneurship and } \\
\text { employment guidance }\end{array}$ & 8 & $\begin{array}{l}\text { Recruitment and } \\
\text { employment office }\end{array}$ & $\begin{array}{c}\text { KAB } \\
\text { entrepreneurship } \\
\text { education } \\
\text { (business } \\
\text { school;32 hours) }\end{array}$ \\
\hline \multirow{2}{*}{$\begin{array}{l}\text { The } 2016 \\
\text { version }\end{array}$} & \multirow{2}{*}{ Yes } & \multirow{2}{*}{$\begin{array}{l}\text { Curriculum of } \\
\text { general } \\
\text { education }\end{array}$} & $\begin{array}{l}\text { College students career } \\
\text { planning and } \\
\text { entrepreneurship } \\
\text { education }\end{array}$ & 16 & $\begin{array}{l}\text { Recruitment and } \\
\text { employment office }\end{array}$ & $\begin{array}{c}\text { KAB } \\
\text { entrepreneurship } \\
\text { education } \\
\text { (business } \\
\text { school;32 hours) } \\
\end{array}$ \\
\hline & & & $\begin{array}{l}\text { Innovation and } \\
\text { entrepreneurship } \\
\text { attainment }\end{array}$ & 24 or 16 & $\begin{array}{l}\text { School-level } \\
\text { optional course } \\
\text { (network) }\end{array}$ & $\begin{array}{l}\text { Transformation } \\
\text { professional } \\
\text { "practice } \\
\text { innovation credit" } \\
(240)\end{array}$ \\
\hline
\end{tabular}

B. The "open class mode" is flawed, the effect is worth reflecting

In 2016, we held an education promotion conference for innovation and entrepreneurship, we take practical action to respond to the call for transformation and entrepreneurship education. Therefore, in the 2016 edition of the talent training program, the "practice innovation credit" of 240 academic hours was set up for the transformation specialty. Let's take this course as a direct point to "innovation and entrepreneurship education", however, there is no detailed plan in many professional training programs to know exactly what the courses are and how to implement them, the effect remains to be seen.

So, currently, on behalf of the teaching of education in our university is only a school-level elective course based on "online courses" and "entrepreneurship and employment guidance" (see 1), which is based on "general knowledge of education". Among them, school-level elective courses cannot effectively support the in-depth development of entrepreneurship education. As to this point, it is discussed in our earlier related research, we're not going to repeat that [4]. The latter is generally 24 hours or 8 hours, and it is arranged by the recruitment and employment office to arrange the teachers' classes, and the main teachers are the counselors of the colleges. This kind of teaching management and teaching task arrangement, even dare not to say what problem will be brought due to the teaching level of the counselor, but at least it reflects the schools have not given enough attention to the idea and consciousness of entrepreneurship education. Moreover, "entrepreneurship and employment guidance" is usually placed in senior year, as a student "employment guidance". Therefore, limited learning hours, combined with its teaching organization management model and core appeal of curriculum setting, it is doomed that "entrepreneurship and employment guidance" has not had a good effect on innovation and entrepreneurship education. The 2016 edition of the talent training program, has set up the "education for college students career planning and entrepreneurship" (16 hours) and "career guidance for college students" (16 hours). This can be seen as an improvement on the above issues, in order to highlight "innovative entrepreneurship" and "employment". However, it is still open as "the general knowledge of education", still not included in the professional curriculum management mode of the colleges, and the effect remains to be tested.

\section{THE DIRECT PARTICIPATION OF FULL-TIME TEACHERS IN ENTREPRENEURSHIP EDUCATION IS NOT ENOUGH, AND THE CORE CONSTRUCTION STRENGTH IS THIN}

The development of education business in the university requires the attention and participation of the leadership and functional departments, and need the active involvement of dedicated teachers in the line of teaching. We need them to continue to be enthusiastic about courses, teaching methods, teaching research, mentoring student's innovation, and other aspects. However, in this regard, the direct participation of local university teachers in the business of education is not enough, resulting in a weak construction force.

On this point, we can examine the number and quality of research papers on entrepreneurship education, and the quantity and quality of research papers. But a more important indicator is how many dedicated teachers are willing to even devote to the teaching of entrepreneurship education related courses. We can illustrate this problem with the acquisition of "KAB entrepreneurship education lecturer qualification" (table 2). Huanghuai college is a typical example of national entrepreneurship education, we can see it by comparison that only two teachers in our school received the "KAB entrepreneurship education lecturer qualification" (voluntary application) in 2010, and in 2010 and 2011, there were only 2 people and 1 in Huanghuai college, but there were 35 and 36 in 2014 and 2016 respectively. So much participating in the 
certification of "KAB entrepreneurship education lecturers", this suggests that this has been raised by "the spontaneous behavior of teachers" to "the organizational behavior of the school". The school promotes dedicated teachers to participate in entrepreneurship education by this. In this regard, local colleges and universities need to study the typical "Huanghuai College".

TABLE II. COMPARISON BETWEEN OUR SCHOOL AND HUANGHUAI COLLEGE'S ACQUISITION OF "KAB ENTREPRENEURSHIP EDUCATION LECTURER QUALIFICATION"

\begin{tabular}{|c|c|c|}
\hline School & Huanggang Normal University & Huanghuai college \\
\hline 2009 & 0 & 0 \\
2010 & 2(Sun Caihong, Ding Houchun) & 2(Xu Cheng, Pan Hao) \\
2011 & 0 & 1(Tang Zhen) \\
2012 & 0 & 0 \\
2014 & 0 & 35 (Note 1) \\
2015 & 0 & 0 \\
2016 & 0 & $36($ Note 2) \\
\hline
\end{tabular}

Note 1: The specific list can be referenced http://chuangye.cyol.com/content/2014-03/06/content_9753109.htm Note 2: The specific list can be referenced http://chuangye.cyol.com/content/2016-03/18/content_12311681.htm

And what I want to explain here is that, "KAB entrepreneurship education" is a project of the communist youth league dedicated to entrepreneurship education. It is one of the core strengths of education development in Chinese universities. Up to February 2016, the KAB project has trained 7,242 professional lecturers from 1,424 colleges and universities. In addition, the university has established the $\mathrm{KAB}$ entrepreneurship club of university students in 305 universities, and more than two million college students have participated in the course study. It has led to more than 1200 universities, including Tsinghua university, China youth political college and Zhejiang university, which have opened the college students KAB foundation course [5]. "KAB entrepreneurship education lecturer qualification" certification has strict training and assessment requirements, it is the supervisor who has opened the education teaching faculty for training qualified entrepreneur education teaching staff. Therefore, "KAB entrepreneurship education lecturer qualification", on the one hand it can reflect the scale and level of teaching staff of entrepreneurship education teaching, and more important is that it can reflect the school teachers' intention and motivation for this job.

\section{IV. "COMPETITION LEAD" HAS LIMITED PRACTICAL EFFECT}

"Competition" is a component of education, "Competition lead" is also a very good teaching idea and method, so many schools and colleges adopt it. But the key word for this teaching philosophy is "lead", competition is not a goal, but a means. We can illustrate this problem with the basic architecture of the entrepreneurship education training model (see figure 1) with the help of "dual platform and dual level". The training model divided entrepreneurship education into "popularization layer entrepreneurship education" and "promotion layer entrepreneurship education", and the former is the base of the latter, "Competition" is also on the second level of "three classroom teaching platforms", its foundation is "entrepreneurship theory classroom" which is at the first level. As we can see from the previous analysis, the "entrepreneurship theory classroom" of local universities is very weak. This is true for both the number of courses, the effectiveness of teaching and the teaching faculty. Therefore, the "competition" activity in the second class is actually lack of foundation. "Competition leads" is actually in the "uncited" state. 


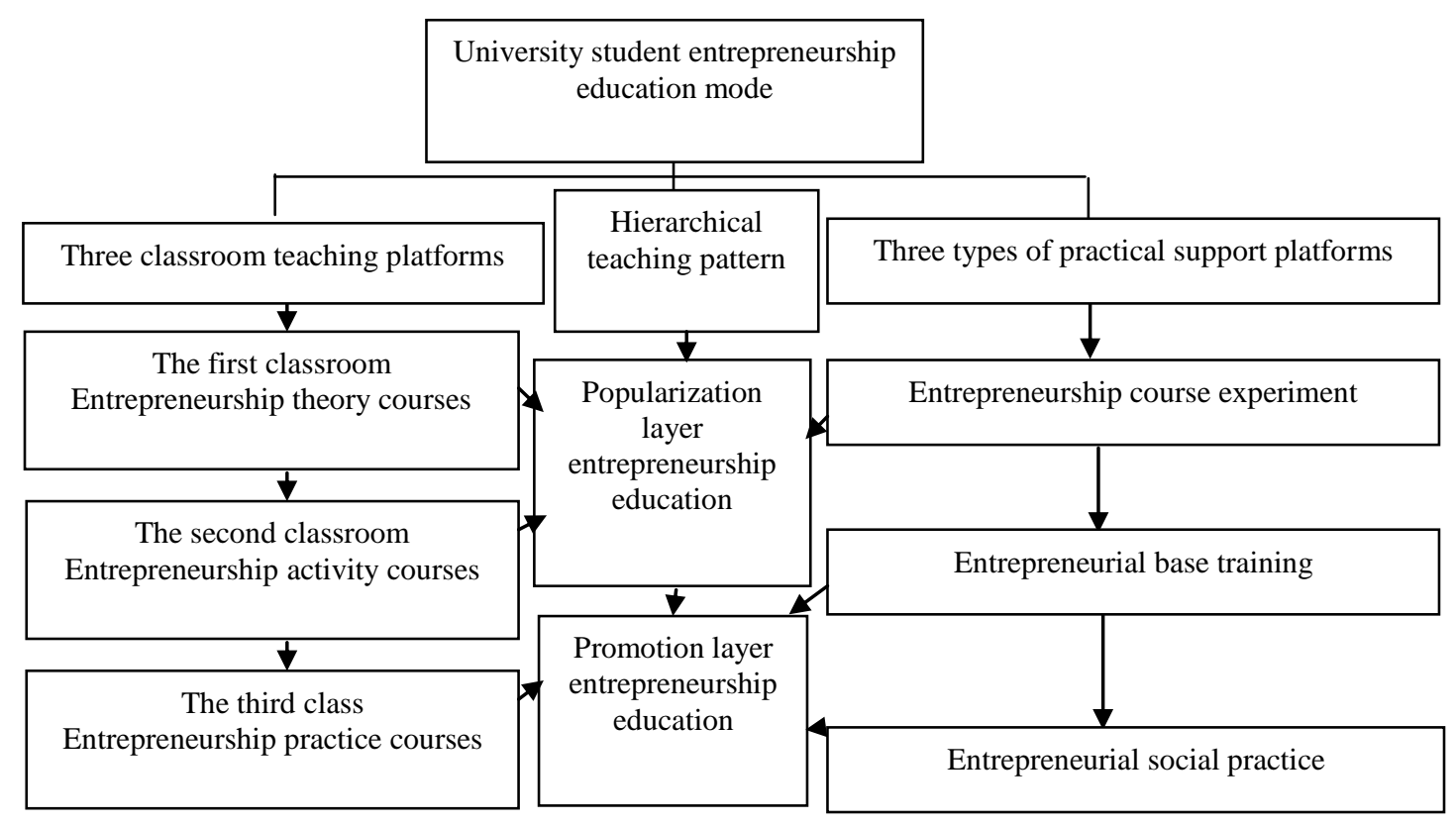

Fig. 1. Basic structure of the entrepreneurship education training mode of "dual platform and dual level" [6]

Due to the lack of a solid and broad base, only the "competition award effect" is left for our school's "professional competition activities". When schools and colleges were trumpeting their student activity awards, they failed to consider how many students had benefited from the award, and how many students had been attracted. Whether through the way of layers of docking to organize the intramural competition in the university to play "the leading role of competition", and there was no summary after the competition. Even a lot of competition, in the case of "professional teacher accountability system" (professional teachers almost assume the competition's application, planning, student organization, training, lead team, etc.), gradually evolved into a "small scope for elite students" selection. There is no selection for the whole school or the whole college, "Competition lead" has become "elite engineering" to a certain extent, with limited benefits.

\section{EMPHASIS ON HARDWARE AND BELITTLE SOFTWARE, THE INTEGRATED OPERATION OF INSTITUTIONAL PLATFORM NEEDS OPTIMIZATION}

The development of entrepreneurship education of university needs "teaching, research, teachers, students and platform" five integrated development [7]. Among them, the platform can provide the strategy, capital, system and daily management guarantee for the development of education. We can find out from the entrepreneurship education platform in our university (see table 3), since 2010, we have established a number of education centers, bases and management institutions in and out of our school. However, these platforms have not yet led our university's business and education to a better level and status, there is no real unique advantage in the region or within the province (though the promotional level of typical entrepreneurship is influential). In particular, it is very weak to lay the foundations of "entrepreneurship education pyramid", and that leads to some of the real problems that we've been talking about, it will also let our university's entrepreneurship education lose the following and continuous capital in the case of overdraft of "typical entrepreneurial appeal ".

TABLE III. STATISTICS OF ENTREPRENEURSHIP EDUCATION RELATED CENTERS AND BASES IN OUR SCHOOL

\begin{tabular}{|c|c|c|}
\hline The name of the base & Approval of the unit & The construction of the year \\
\hline $\begin{array}{c}\text { College student entrepreneurship practice } \\
\text { alliance }\end{array}$ & $\begin{array}{c}\text { Huanggang Normal } \\
\text { University }\end{array}$ & 2010 \\
\hline $\begin{array}{c}\text { College student KAB entrepreneurship } \\
\text { education base }\end{array}$ & $\begin{array}{l}\text { The Central Committee } \\
\text { of the Communist Young } \\
\text { League }\end{array}$ & 2011 \\
\hline
\end{tabular}




\begin{tabular}{|c|c|c|}
\hline \multicolumn{2}{|c|}{ Table III, cont. } \\
\hline $\begin{array}{c}\text { Huanggang Dabie mountain youth talent } \\
\text { entrepreneurship and innovation association }\end{array}$ & Huanggang & 2012 \\
\hline $\begin{array}{c}\text { A demonstration base for college students } \\
\text { in Hubei province }\end{array}$ & $\begin{array}{c}\text { Hubei provincial } \\
\text { education department }\end{array}$ & 2013 \\
\hline $\begin{array}{c}\text { Economic management and } \\
\text { entrepreneurship experimental teaching } \\
\text { demonstration center }\end{array}$ & $\begin{array}{c}\text { Hubei provincial } \\
\text { education department }\end{array}$ & 2014 \\
\hline $\begin{array}{c}\text { Hubei university student entrepreneurship } \\
\text { club }\end{array}$ & $\begin{array}{c}\text { Hubei provincial } \\
\text { education department }\end{array}$ & 2014 \\
\hline $\begin{array}{c}\text { College student innovation and } \\
\text { entrepreneurship center }\end{array}$ & $\begin{array}{c}\text { Huanggang Normal } \\
\text { University }\end{array}$ & 2015 \\
\hline $\begin{array}{c}\text { Music college student entrepreneurship } \\
\text { service center }\end{array}$ & Music college \\
\hline $\begin{array}{c}\text { Student entrepreneurship management } \\
\text { office }\end{array}$ & Secondary colleges & ---- \\
\hline
\end{tabular}

Especially from the daily operation, these institutions have not formed the daily, regular, and brand impact activities on campus, it is more to be "listed actively, run rambling". For example, the "college student KAB entrepreneurship education base" awarded by the communist youth league is not funded by the approval department, and it has not been taken seriously in school, it also lost the opportunity to communicate and function internally. There is also no large-scale and regularized resource support for Huanggang Dabie mountain youth talent entrepreneurship and innovation association. The college students' entrepreneurial management office was not seen the effective and effective daily work, some colleges' listed offices have been locked for years. There has not been an orderly process and situation in the organization and management of students' professional competitions. Professional teachers who guide professional competitions often become organizers of professional events.

\section{CONCLUSION}

From the perspective of reality, education teaching in local colleges and universities started late and accumulated less. There are defects in the course model, the effect is not good, and the participation of professional teachers is not enough. "Competition lead" has limited effect, as well as the low efficiency of collaborative operation of various institutions on campus, these are the typical symptoms of current entrepreneurship education in local universities and colleges. Attaching importance to and solving these problems is essential to the development of education "popularization" of local universities and colleges.
Note: "year of construction" information is from the campus network news promotion column.

\section{ACKNOWLEDGMENT}

Fund Project: Hubei Province Education Science Planning 2016 degree project (2016GA036), Huanggang Normal University teaching and research project (2015CE31), Huanggang Normal College 2016 annual development of the practice of brand building project (zxfz2016B034).

\section{REFERENCES}

[1] Yue Changjun, Public entrepreneurship, education first [N]. Social science news, the fourth edition of total 1467.

[2] Li Weiming, Li Chunyan, Du Xiaohua, Chinese university entrepreneurship education for ten years: evolution, problems and system construction [J]. Education research, 2013 (06) : 42-51.

[3] Liu Linqing, Xia Qinghua, Zhou Lu, The first exploration of entrepreneurial ecosystem of entrepreneurial universities -- taking MIT as an example [J]. Research of higher education, 2009 (03) : 19-26.

[4] Ding Houchun, Jiang Li, Reflection on the promotion mode of "schoollevel elective courses" for KAB entrepreneurship education [J]. 2013 conference on Education and Teaching in colleges and Universities (ISBN: 978-957-43-0604-6), 2013.10.

[5] KAB entrepreneurship education (China) project profile [EB/OL]. KAB entrepreneurship education network [2016-04-12] http://chuangye.cyol.com/content/2016-04/12/content_12407838.htm.

[6] Yu Jinbo, The scientific construction and operation of entrepreneurship education training model for college students $[\mathrm{J}]$. Gao jiao exploration, 2012 (2) : 137-139.

[7] Ding Houchun, Jiang Li, Some ideas on the development of education of university entrepreneurship, based on the experience of education promotion and application of KAB business in our university [J]. Journal of Huanggang normal university, 2013 (2) : 122-125. 